\title{
How Keynes came to Britain
}

\author{
Robert Skidelsky \\ Emeritus Professor of Political Economy, University of Warwick and Chairman, Centre for Global Studies, \\ London, UK
}

I explore how Keynesian ideas made their way into British public policy. I argue that the breakdown of pre-First World War macroeconomic conditions led to a 'blocked' system, where the adjustment mechanisms presupposed by classical economics were jammed, and that Keynesian economics offered an escape from this system. I explain the Keynesian response to the new problems in monetary and fiscal policy: the gold standard impeding credit control, and the tenacity of the balanced budget rule, respectively. Finally, I outline how Keynes's ideas took hold after the Great Depression via the events at the Macmillan Committee, and their policy implications.

Keywords: Keynes, Keynesian economics, the Great Depression, economic thought, history of economic thought, macroeconomics, monetary policy, fiscal policy, economic history, the Keynesian revolution

JEL codes: $B 220, N 140, E 120, E 630$

'[I]t would promote confidence and furnish an objective standard of value, if ... the authorities would employ all their resources to prevent a movement of [the price level] by more than a certain percentage in either direction away from the normal.'

John Maynard Keynes (1923 [1978], p. 148)

'Very little additional employment and no permanent employment can in fact and as a general rule be created by State borrowing and State expenditure.'

Winston Churchill (HC Deb 15 April 1929, vol. 227, col. 54)

'When every country turned to protect its national private interest, the world public interest went down the drain.'

Charles P. Kindleberger (1973, pp. 290-291)

\section{THE BLOCKED SOCIETY}

After the First World War, the macroeconomic policy rules of the previous half-century broke down. This was because the conditions making it possible to keep them disappeared. The old macro-economy (in the days before macroeconomic policy) was framed by three connected rules: adherence to the gold standard, balanced budgets, free trade. All three were unhinged by the war. Quite simply, the gold standard became the transmitter, rather than the dampener, of external shocks, while domestic adjustment to them became more costly.

Because of increased union control over wages, increased working-class influence on politics, and the shutting-off of emigration outlets, domestic economies had become more rigid. Long before 'stickiness' of wages and prices found their way into formal 
economic models, it was becoming evident that industrial economies had lost their previous 'elasticity'. The liquid markets praised by economists had morphed into a congealed corporatist mass. Germany was the main example of this (Maier 1975). Fiscal rules based on balanced budgets and free trade became increasingly difficult to maintain.

The nineteenth century gold standard had worked after a fashion owing to special conditions. After the war it became completely dysfunctional. Barry Eichengreen (1985, p. 22) paints a compelling picture of 'an international monetary system disturbed by misaligned exchange rates, insufficient and unhelpfully distributed reserves ... and at the same time incapable of responding to disturbances due to rigidities in wage structure, rising tariffs, and the failure of cooperation'. London was fatally weakened as a 'conductor of the international orchestra'. The problem of 'global imbalances' reared its head for the first time, but by no means the last time, with the USA's permanent export surplus exerting deflationary pressure on much of the rest of the world.

In short, the adjustment mechanisms assumed by classical economics were blocked or jammed. Unemployment became the chief expression of market sclerosis, and the main challenge to economic policy. Unemployment in Germany and Britain averaged about 10 per cent in the 1920s, double what it had been before the First World War. Persisting mass unemployment was also a challenge to theory. There was no theory of output and employment as such, since classical theory assumed - perhaps presupposed would be better - a state of full employment. Experience validated this to some extent. Economies might be knocked over for a short time, but they got up again without government help. Say's law was not mortally challenged. This changed with the Great Depression, which started in 1929 and from which the world did not fully recover until the Second World War.

Theory and policy alike were slow to recognize that conditions had changed. Under the slogan 'Back to normalcy', determined attempts were made in the 1920s to restore the prewar system. At their heart was the restoration of the international gold standard. Orthodoxy saw this as the indispensable framework for domestic monetary discipline. A gold anchor was politician-proof. To restore the gold standard, suspended in the war, it was, according to the Financial Resolution of the Genoa Conference of 1922, essential for governments 'to balance national budgets by contraction of expenses rather than by increase in taxation, to stop inflation by ceasing to cover budget deficits by recourse to paper money, and to cease borrowing for unproductive purposes' (Brown 1940 , p. 343) - in short, to liquidate war finance. The old post-Napoleonic Ricardian programme became the consensual position of all governments.

The Great Depression of 1929-1932 started a period of experiments in macroeconomic policy and theory from which the Keynesian Revolution eventually emerged triumphant.

This essay will consider the way in which macro policy adapted, or failed to adapt, to the new conditions, with the Great Depression as the traumatic break in trend.

\section{THE PROBLEM WITH MONEY}

Before the First World War, monetary reformers like Fisher and Wicksell had urged that central banks should deliberately use monetary policy to stabilize the price level, and not just be automatic transmitters of international gold flows to the domestic economy. Central bankers paid little attention to their advice. The 'management' of the gold standard had started, but it had not got very far.

Once it was accepted as prudent, for social reasons, to use monetary policy to prevent dislocating economic fluctuations, all the unsettled questions in monetary 
theory were reopened. Was the money supply exogenous or endogenous? Was the task of the central bank to control currency or credit? Was it possible to combine price stability with exchange-rate stability? These questions, left over from the prewar era, were initially debated in the context of liquidating the wartime and postwar inflations, which in Germany and other central and east European countries reached hyperinflation. Later the discussions took place in conditions of unprecedented deflation.

During and after the war, Keynes and Edwin Cannan, professor of economics at the LSE, debated the causes of the wartime and postwar inflation. In a re-run of the bullionist-real bills controversy of the early nineteenth century, Cannan denied that banks create money. To him they were simply 'middlemen', like the old silversmiths who lent out, for interest, what had been deposited with them for safekeeping. They could not lend out more money than they had received, or they would go bust. It was the central bank that produced the 'extra' money: the money supply was exogenous. Thus the problem of stopping inflation boiled down to limiting the issue of central bank notes. 'Burn your paper money, and go on burning it until it will buy as much goods as it used to', Cannan wrote in his book The Paper Pound in 1919. The great virtue of the gold standard was that it made the issue of money knave-proof.

Keynes restated the real bills argument. Money was issued in response to 'needs of trade': it was, that is, endogenous. It could not therefore be in 'over-supply'. Old-fashioned theorists like Cannan claimed that credit expansion followed currency expansion. But, wrote Keynes, in a modern community with a developed banking system, expansion of notes was 'generally the last phase of a lengthy process of credit creation'. To reverse the credit expansion after it had occurred by preventing the quantity of notes from increasing would only bankrupt the business world - 'a course often followed in former days when Professor Cannan's doctrine still held the field' (Skidelsky 1992, pp. 162-164). Control of credit, not control of currency, was the key to price and - by extension - economic stability.

Keynes was right. The banks held huge quantities of short-term Treasury bills, issued by the government to finance its war expenditure, which fell due for repayment after the war. 'This meant that after the war the banks could supplement their cash reserves by not subscribing for new Treasury bills when the old ones matured, and consequently the monetary authorities had been powerless to prevent a great expansion of credit during the postwar boom of 1919-20' (Peden 1993, p. 228).

How was credit to be controlled? The Wicksellian answer was to set market rates of interest equal to the 'natural' rate. By setting the bank rate (the overnight rate at which it would lend to the commercial banks), the central bank could control the long-rate (the rates at which commercial banks lent to their customers). Bank-rate policy should be supplemented by open-market policy, acting directly on banks' cash reserves. Keynes wrote (1930b [1978], p. 424):

A central bank, which is free to govern the volume of cash and reserve money in its monetary system by the joint use of bank rate policy and open-market operations, is ... in a position to control not merely the volume of credit but the rate of investment, the level of prices and in the long run the level of incomes, provided that the objectives it sets before it are compatible with ... maintenance of gold convertibility.

There was the rub. Standing in the way of credit control was the gold standard. Bank Rate could be used either to stabilize the exchange rate or domestic prices. It could not do both.

In the late nineteenth century the problem had, to some extent, been finessed by flexibility of central bank responses to gold movements, but above all by the hegemonic role of sterling in the international payments system. As Charles Kindleberger (1973) tells it, 
sterling's position rested on three factors: (a) its superior credibility, derived from it having maintained its peacetime value against gold since 1717, which made it the preferred reserve currency of the system; (b) London's position as the hub of the international payments system, with trade balances typically settled by transfer between bank balances held in London; and (c) Britain's position as the world's main foreign lender, both short and long. In Kindleberger's summary, Britain had stabilized the prewar monetary system in three particulars: (a) maintaining a policy of free imports; (b) providing counter-cyclical long-term lending; and (c) discounting in crisis. After the war, the system was rendered unstable by 'British inability and United States unwillingness' (ibid., p. 291) to assume these responsibilities.

The 'hegemonic thesis' has been challenged by Barry Eichengreen (1995, pp. 5-9). Eichengreen says that the prewar system depended on credibility and cooperation. The franc and mark were just as credible as sterling. The system was further stabilized through 'overt, conscious cooperation among central banks and governments' (ibid., p. 8). After the war, domestic social and political pressures reduced credibility, and international political disorganization, including the war debt imbroglio, minimized financial and political cooperation.

While the Bank of England, backed by the government and the 'sound men' of finance, demanded the rapid resumption of gold-sterling convertibility at the prewar parity - any reduction in the gold price of sterling being considered akin to medieval debasement of the coinage - the left in politics was quick to finger the gold standard as the source of Britain's postwar woes. The government had suspended convertibility in 1919. Prices skyrocketed, the exchange rate plummeted. Bank Rate was put up to 7 per cent in 1920 to check the inflationary boom, a reasonable step in the circumstances, but it was then held at a punitive rate in the subsequent year and a half of collapsing prices, output, and employment in order to prepare for a resumption of convertibility at the old sterling-dollar exchange rate. Was it cheap money that caused the boom and dear money that ended it? Or was it pent-up wartime demand that caused prices to rise, followed by a sudden faltering of confidence? On such questions monetary theorists have always been divided.

At the time, Keynes had no doubt that the boom-bust sequence had monetary causes. In the true spirit of the monetary reformer, he condemned the gold standard as a 'barbarous relic' in his Tract on Monetary Reform (1923 [1978]), and attacked the aim of stabilizing sterling at its prewar parity with gold - in practice, with the undepreciated dollar, at an exchange rate of $£ 1$ : $\$ 4.76$. It was to no avail. The aim of policy-makers was to restore the international gold standard as soon as possible to prevent inflation. Germany went back in 1924, Britain in 1925, France and Italy in 1927. Only the United States had full freedom to try out the ideas of the monetary reformers. It had not had to devalue the dollar against gold in the war, and its current-account surpluses produced a steady inflow of gold into the Treasury's strong box, Fort Knox. By 'sterilizing' these inflows, the Federal Reserve System - established in 1913 - could insulate the domestic value of the dollar from that of gold, negating Hume's price-specie flow mechanism. Because it did not have to worry about the balance of payments, it was the only country in a position to try out the ideas of the money reformers.

Maintaining stable prices in the US between 1923 and 1928 by means of interest-rate policy and open-market operations was considered a triumphant vindication of the 'scientific' monetary policy pursued by the US Federal Reserve Board, and particularly its governor, Benjamin Strong. However, a less noticed consequence of 'sterilization' was that it blocked the international adjustment mechanism. The dollar became progressively 
undervalued, as did the French franc which had stabilized the gold-franc exchange rate in 1927 at a large discount to the pound. These two gold 'hoarders', which by 1929 had amassed 60 per cent of the world's monetary gold stock, exerted a deflationary pressure on the rest of the gold standard world.

Triumph turned to ashes when the Fed failed to prevent the collapse of the US economy in the Great Depression of 1929-1932. What the Fed ought to have done, according to Milton Friedman, was to expand its open-market operations - buying investments - to whatever extent was needed to prevent the contraction of credit. In practice, open-market operations on a large scale started only in 1932.

Friedman and Schwartz (1965, p. x) wrote:

The drastic decline in the quantity of money during those years and the occurrence of a banking panic of unprecedented severity ... did not reflect the absence of power on the part of the Federal Reserve System to prevent them. Throughout the contraction, the System had ample powers to cut short the tragic process of monetary deflation and banking collapse. Had it used those powers effectively in late 1930 or even in early or mid-1931, the excessive liquidity crises ... could almost certainly have been prevented and the stock of money kept from declining or, indeed, increased to any desired extent. Such action would have eased the severity of the contraction and very likely would have brought it to an end at a much earlier date.

Keynes would have agreed with this analysis at the start of the Depression: in 1930 (Keynes 1930a [1978]) he advocated open-market operations 'à outrance' - buying government securities to whatever extent was needed - to cut off a downward slide. This is now called quantitative easing. But by the early 1930s he doubted that monetary policy alone could either maintain stability or prevent collapses.

\section{THE PROBLEM WITH FISCAL POLICY}

The war challenged not only the traditional view of monetary policy but the Victorian ideal of the minimal state. The two were related: sound finance was needed to maintain confidence in the currency. In Britain, state expenditure, fiscal deficits and the national debt all rose to heights not seen since the Napoleonic wars.

This 'involuntary' growth of the state was initially assumed to be a wartime anomaly. But enhanced social provision was plainly there to stay. After the war, government spending was slashed but UK state spending in the 1920s, at 25 per cent of GDP, was double its prewar level. This meant that the government's fiscal operations had a larger impact on the economy, for good or ill. However, although budgets were potentially usable for stabilization purposes, governments continued firmly to believe that they should be balanced, the balance including a sum set aside to repay the national debt, which, hugely swollen by the war, claimed over 30 per cent of the budget. Adherents of the balanced budget believed that only by confronting advocates of new expenditure with the need to raise money from taxes could there be a check on the inexorable growth of the state. The 'balanced budget' was the symbol of a return to normalcy.

By June 1921, 2.2 million people were out of work and Britain experienced a then record peacetime budget deficit of 7 per cent of national income (Burrows and Cobbin 2009). The Lloyd George coalition government set up a Cabinet Committee on Unemployment which made several proposals for increasing public spending. Particularly striking was a proposal in December 1921 by Sir Edwin Montagu, Secretary of State for India, that the government should deliberately budget for a deficit by reducing income tax, with the expectation that the borrowing requirement would decline as the 
tax cuts revived the economy and therefore the government's revenue (Peden 2000). It was against these supposedly improvident plans that the 'Treasury View' defined itself. In a note to this Committee, Sir Otto Niemeyer (1921), controller of finance at the Treasury, explained that unemployment was not due to insufficient demand, but excessive wage costs: 'The earnings of British industry are not sufficient to pay the present scale of wages all round. Consequently if present wages are to be maintained a certain fraction of the population must go without wages. The practical manifestation of which is unemployment'. Niemeyer (1921), cited in Skidelsky (1981, pp. 171-172), warned that a 'very large proportion' of any additional borrowings would, in the absence of inflation, be diverting money which would otherwise have been used 'soon' by private industry.

These arguments carried the day. Under intense pressure to cut taxes while simultaneously balancing the budget, the Government in 1921 appointed Sir Eric Geddes to head a committee charged with finding additional savings of $£ 87$ million. In what became known as the 'Geddes Axe', government spending was slashed by 25 per cent - this percentage of current public spending being roughly $£ 100$ billion in today's terms thereby undermining an already fragile economy (see Skidelsky 2015; Burrows and Cobbin 2009). Defending the Axe, Baldwin, the new Chancellor, repeated that 'money taken for government purposes is money taken away from trade, and borrowing will thus tend to depress trade and increase unemployment' (Middlemas and Barnes 1969, p. 127). Budget balance was restored in 1922-1923 partly by the 'window dressing' of accounts. But contrary to the reasoning behind the Geddes Axe, the cuts in government spending increased the national debt from 135 per cent of GDP in 1919 to 180 per cent in 1923. The economy bounced back after a year, but never regained anything like full employment for the rest of the 1920s. The 1990s is said to have been Japan's lost decade; the 1920s was Britain's.

A technical issue which has loomed large in discussions of fiscal policy since the 1920s is what is meant by a balanced budget. The difficulties of balancing the budget in the 1920s in the face of stagnant revenues and rising social expenditures led to a great deal of 'off-budget' borrowing by quasi-government agencies for telephones, roads and public utilities. There was also an Unemployment Insurance Fund, which was supposed to 'balance' in normal times, and became a significant budgetary charge only when rising unemployment made it impossible for the Fund to balance. Balancing the budget meant balancing current spending with revenue. The Treasury's condition for authorizing borrowing by public utilities till at least 1935 was that the money return on investment should be enough to pay off both interest and capital on the loan, and therefore not add to the central government's deficit. There was no published figure of Net Public Sector Borrowing till 1968. So the real economic question was not whether there should be a budget deficit but what the effects of borrowing 'off-budget' would have on the economy. This was the issue raised by the Lloyd George 'pledge' of 1929.

In the run-up to the General Election of 1929, the Liberal leader Lloyd George promised that a Liberal government, the Conservatives then being in power, would borrow $£ 250 \mathrm{~m}$ for a two-year programme of infrastructure development to get rid of what he called 'abnormal' unemployment - the same figure that he suggested in 1921, being approximately 5 per cent of GDP at 1921 prices. Keynes and fellow-economist Hubert Henderson wrote an enthusiastic endorsement, Can Lloyd George Do It? (Keynes and Henderson 1929). The extra state spending, they argued, would create a 'cumulative wave of prosperity'. The Chancellor, Winston Churchill, turned to the Treasury for advice. He thought the Lloyd George-Keynes proposals made a lot of sense.

To refute the Lloyd George-Keynes argument, the Treasury dusted down a halfforgotten memorandum of 1925 by its only professional economist, Ralph Hawtrey. 
Hawtrey is credited with crystallizing the traditional Treasury prejudice against 'wasteful' government expenditure into a formal 'Treasury View'. He had stated one part of the Ricardian doctrine with Ricardian clarity in 1913: 'the Government by the very act of borrowing for [state] expenditure is withdrawing from the investment market saving which would otherwise be applied to the creation of capital' (Hawtrey 1913 [1962], p. 120). This remained his view in a more nuanced exposition in 1925. Government borrowing of 'genuine savings' would 'crowd out' an equivalent amount of private investment. (Of course, this was not true if the government could borrow 'genuine' savings from abroad, a view also championed by Keynes.) It could create additional employment only by borrowing the money from the Bank of England, because then additional bank 'savings' would be created, allowing banks to expand credit to private borrowers. But in this case it was the monetary expansion, not government spending on public works, that would cause the increased employment. Public works were simply a 'piece of ritual' (Hawtrey 1925, p. 112). But Hawtrey made an exception: if Bank Rate had fallen to 2 per cent without reviving business confidence - that is, the velocity of money had fallen to a low level - a gilt-edged loan for government investment, attractively priced, would be justified. This was an important concession to what came to be known as the liquidity-preference theory of the rate of interest. But with interest rates ranging from 4 per cent to 6.5 per cent in the 1920s to maintain the gold standard, Hawtrey thought this argument irrelevant to the circumstances, and the Treasury made no use of it in its response to Lloyd George. Instead it equipped the Prime Minister Baldwin with a standard response to the Lloyd George proposals, that "we must either take existing money or create new money': state spending on public works would either be diversionary or inflationary. And inflation was ruled out by adherence to the gold standard. Suitably primed, Churchill rubbished the Lloyd George plan in his budget speech of 1929 by stating that: 'The orthodox Treasury view ... is that when the Government borrow $[\mathrm{s}]$ in the money market it becomes a new competitor with industry and engrosses to itself resources which would otherwise have been employed by private enterprise, and in the process raises the rent of money to all who have needed of it' (cited in Peden 2004, p. 57). The full employment assumption behind these pronouncements was barely hidden.

Could Lloyd George have done it? The argument turns on the size of the multiplier, the concept of which was only developed in 1931. Richard Kahn estimated in 1931 that 1.88 was the most realistic estimate of the multiplier; subsequent research has suggested that 1.5 was closer to the mark, and then only after an interlude of time (Peden 2000, p. 231). This would have created between 650000 and 865000 jobs, enough to have had a big impact on unemployment (1.25m of insured workers in 1929), and mitigated the impact of the world depression that struck in 1931.

The Labour government elected in 1929 implemented a small part of the Lloyd George programme - far too small to make much impact on the rising numbers of unemployment, but enough to alarm the Treasury. In December 1929, the Treasury's new Controller of Finance, Sir Richard Hopkins, warned against borrowing for roads: 'A road, however useful it may be produces no revenue to the State; it does not provide the interest and Sinking Fund on any loan raised. Accordingly, therefore, according to time-honoured principles of public finance it should be paid for out of revenue' (Peden 2000, p. 226).

The deepening depression - unemployment rose from 10.4 per cent in 1929 to almost 20 per cent in 1931 - left Philip Snowden, Chancellor of the Exchequer, with a rising deficit. He appointed the May Committee to advise him on fiscal retrenchment. The May Committee reported that the government faced a prospective deficit for 1931-1932 of $£ 120$ m, or 5 per cent of GDP. The deficit projected by the 
May Committee was as inaccurately (and ideologically) alarmist as similar projections in 2010. It counted all borrowing for the Unemployment and Road funds (not then part of the budget) as current expenditure, as well as $£ 50 \mathrm{~m}$ for debt redemption.

The political debate now took a form which has recently become familiar. The Conservative opposition blamed the deficit on the extravagance of the Labour government and demanded cuts in 'wasteful' public spending, especially on unemployment benefits. Labour said the hole in the budget was due to the hole in the economy. The minority Labour government refused to implement the full scale of the spending cuts recommended by the May Committee. As a consequence, the Prime Minister, Ramsay MacDonald and his Chancellor joined the Conservatives and Liberals in a National Government in August 1931, while Labour went into opposition.

Faced with a prospective deficit, revised to $£ 170 \mathrm{~m}$, the National Government legislated an $£ 82 \mathrm{~m}$ hike in taxes, and economies of $£ 70 \mathrm{~m}$. With its allocation of $£ 20 \mathrm{~m}$ for debt repayment, this was really the last hurrah of the Victorian balanced budget rule. It was also the end of the gold standard. Sound finance was supposed to maintain confidence in the currency, but the economy measures failed to prevent a continuing flight from sterling, as the merchant banks of the City of London were seen to have borrowed short and lent long to failed and failing banks on the Continent of Europe. No foreign funds were available for 'bail-out' and the obligation to exchange sterling for gold was suspended on 21 September 1931, never to be restored. A combination of devaluation, cheap money and Protection enabled the budget, minus sinking fund, to be balanced from 1933-1937, but unemployment was slow to come down. Lloyd George went on trying, campaigning for a big public works programme in 1935. This time the Treasury was more encouraging: while public works were useless as a remedy for depression, they might maintain the momentum of recovery. But the Conservative Chancellor, Neville Chamberlain, stuck to the older orthodoxy that state spending was au fond wasteful, and refused to allocate more than a tiny dollop of money to the 'special areas' of exceptionally high unemployment. And the Treasury itself was still worrying in 1937 that repeated borrowing might call into question national finance and make it difficult for the government to borrow at low interest rates. There was another economic collapse in 1937-1938. A huge loan-financed rearmament programme finally lifted Britain out of semi-slump ten years after the start of the Great Depression.

Roger Middleton (1985, p. 85) has argued that the tenacity of the balanced budget rule was based on four beliefs: (i) that 'all factors of production are normally and inevitably utilized by private business, [and that] it follows that the State can obtain the use of such factors only by preventing private business from using them' (Schumacher 1944, p. 86, cited in Middleton 1985); (ii) that unbalanced budgets would reduce business confidence and therefore be counterproductive - particularly if they were the result of wasteful public works; (iii) that unbalanced budgets were inflationary; and (iv) that the national debt implied a deadweight loss to productive enterprise. These were the arguments of Ricardo and almost exactly the arguments used by George Osborne's Treasury in 2010. But in 1933 John Maynard Keynes struck a new note. 'Look after the unemployment', he said, 'and the budget will look after itself' (Keynes 1933a [1978], p. 150).

\section{THE MACMILLAN COMMITTEE, 1930}

The Great Depression of 1929-1932 marks the divide between pre-Keynesian and post-Keynesian theories of macroeconomic policy. A key moment in the confrontation 
was Keynes's interrogation of officials of the Bank of England and the Treasury at the Macmillan Committee on Finance and Industry in May 1930.

Part of that orthodoxy was the 'scientific' theory of the monetary reformers. Much to Keynes's surprise, the Bank stolidly denied that it had the power over credit conditions which Keynes claimed for it. The bank rate, claimed the Governor of the Bank, Montagu Norman, affected only 'short money', leaving the 'whole mass of credit' little changed (Skidelsky 1992).

Keynes objected. 'What you are saying', he put to Bank official Walter Stewart, 'is that there is always the right quantity of credit?' Stewart doubted whether 'the expansion of bank credit [sic Central Bank money] in quantity was a determining factor in prices and trade activity ... there are a great many things that people can do with money besides buying commodities. They can hold it'. All that meant, Keynes rejoined, was that the Bank would have to 'dose the system with money', 'feed the hoarder' in order to bring down long-term rates. To which Stewart responded: 'I should not have thought that bank credit determines the long run rate'. Keynes admitted that when a depression had got too deep, a 'negative rate of interest' might be required to bring about economic recovery, but normally 'a reasonably abundant supply of credit would do the trick?' Stewart persisted: 'Only if borrowers saw a prospect of making a profit and of repaying debts'. Keynes was driven to arguing that 'though [the supply of credit] may be only a balancing factor, it is the most controllable factor'. To which Stewart replied: 'It may be the only thing that the Central Bank can do; but it does not strike me as being the only thing that business men can do ... I regard wage adjustments as ever so much more important ... than ... anything bankers can do'. (Quotes from a 1930 meeting of the Macmillan Committee, QQ. 7690-7847, cited from Skidelsky 1992, pp. 357-358.)

Keynes's belief in monetary therapy was shaken, but not shattered. He still believed that when interest rates were lowered, investment projects would become profitable which had not been profitable at the old rates. But he admitted that Bank Rate was a weaker instrument for securing lower rates than he had believed. It was all very well to talk of 'feeding the hoarder', but suppose his appetite was insatiable? The result would be a credit deadlock. By 1932 Keynes was writing:

It may still be the case that the lender, with his confidence shattered by his experience, will continue for new enterprise rates of interest which the borrower cannot expect to earn. ... If this proves to be the case there will be no means of escape from prolonged and perhaps interminable depression except by direct state intervention to promote and subsidise new investment. (Cited in Skidelsky 1992, p. 441)

If business could not be induced to invest, the government could always take its place. At this point, the Treasury View came into Keynes's sights in the person of Sir Richard Hopkins. Keynes thought he knew what the Treasury View was and that he was in a position to refute it. The Treasury had claimed that loan-financed public spending could not add to investment and employment, only divert them from existing uses. This was true, Keynes was prepared to say, only on the assumption of full employment. But Hopkins had foreseen this.

The Treasury was not opposed to government borrowing as such, Hopkins told Keynes, but to the particular plan put forward by Lloyd George. This plan, far from setting up a 'cycle of prosperity' as Keynes had hoped, would much more probably produce a great cry against waste, so the loans would have to be 'put out at a very high price'. The more distrusted the plan was, the higher the rate of interest would have to go. Was not Keynes's advocacy of additional state spending likely to retard the necessary fall in interest rates? 
Keynes had another try. Suppose, instead of borrowing the money from the public, the government borrowed it from the Bank. That was 'fantastic', Hopkins replied. 'If I am right in thinking that a great loan directly raised in the ordinary way would carry with it a bad public sentiment and adverse repercussions ... what would happen if it were raised by what is ordinarily called plain inflation I cannot imagine'. Keynes's attack on the Treasury View was incomplete, since he did not make use of the argument that loan-financed schemes, good or bad, would generate extra capital (saving) and not just make a 'hole' in existing capital. The chairman, Judge Macmillan, concluded: 'I think we can characterize it as a drawn battle' (see Skidelsky 1992, pp. 356-361; for debates on the Treasury View, see Clarke 1988, ch. 3).

Let's stand back for a moment. What Hopkins had done was to invoke what Paul Krugman in 2011 called 'the confidence fairy': the circular view that the effects of a budget deficit depend, right or wrong, on the expected effects of a budget deficit; formally, that it depends on the model of the economy in the minds of the business community. If they believed that a government loan-financed programme of capital investment would make things worse, that belief would cancel any possible beneficial effect of the programme, by causing a spike in interest rates. It was not the state's borrowing per se, but loss of confidence in government finance implied by that borrowing, that would create the 'hole' in private capital.

There is no doubt that Keynes was shaken by Hopkins's confidence fairy. Experience of slump was not itself sufficient to loosen the hold of the old theory. That could only be done by a counter-theory. Keynes's General Theory of 1936 may be seen as his attempt to create a different set of expectations concerning the effects of budgetary policy on the economy.

\section{THE GENERAL THEORY}

In The General Theory of Employment, Interest, and Money (1936 [1978] - hereafter GT), Keynes set out to provide a theory of 'output as a whole'. Why had no one done this before? Because of the assumption that demand was not a problem. The cost of producing goods and services created the incomes to buy them. In a world of scarcity - one in which wants exceeded availabilities - it seemed inconceivable that people would not spend their incomes to buy the goods and services their work had earned. Until humanity reached a state of abundance, there would always be enough demand for what was produced, and that meant enough work for all who wanted it. The problem was to increase supply, for it was this that made the difference between wealth and poverty. But until the point of saturation, it could be assumed, as J.-B. Say put it, that 'supply creates its own demand'.

However, as so often in economics, theory and experience diverged. Economic history was punctuated by plentiful lapses from full employment. The rather prolonged lapses in the 1920s and 1930s suggested, not only to Keynes, that Say's law was not a reliable general rule: there could be a deficiency of aggregate demand. But how exactly could this happen?

Keynes attacked the problem in the most direct way possible (though the GT showed evidence of intellectual torture). Incomes are earned and spent. People spend part of their incomes buying consumption goods and save another part of them. Orthodox economists tacitly believed that saving is just a form of spending on investment (or 'future') goods. This is what Keynes denied. People's 'propensity to consume' - the fraction of their 
incomes which they devote to consumption - is fairly stable. If the fraction of the incomes they choose to save rather than spend on consumption equals the amount businesses want to invest in new 'machines' there will be no unemployment: Say's law holds. But this equality is far from guaranteed. While saving depends on habit, investment depends on 'animal spirits', a 'spontaneous urge to action rather than inaction'. Animal spirits are needed for investment because it is such an uncertain business. Expected returns are in the nature of gambles on the future with no calculable odds. 'Thus', Keynes wrote, 'if the animal spirits are dimmed and the spontaneous optimism falters, leaving us to depend on nothing but a mathematical expectation, enterprise will fade and die ... even though fears of loss may have a basis no more reasonable than hopes of profit had before' (Keynes 1936 [1978], pp. 161-162).

It is the instability of investment that undermines Say's law. It causes the business cycle. But worse than this, a shock to investment sets up a chain of repercussions on income and employment that causes 'output as a whole' to subside to a lower level and stay there until some stimulating events occur. Incomes fall as unemployment rises, so less output can be bought. Output is curtailed to the point at which it can all be bought by the reduced level of spending. Saving falls to the point when it is no longer in excess of investment. These are equivalent points of equilibrium:

$$
\begin{aligned}
& Y=C(y)+I(r, m e c) \\
& S=I .
\end{aligned}
$$

But this need not be a full employment equilibrium: it could be an under-employment equilibrium. Keynes's great innovation - especially from the point of view of policy was not to demonstrate the instability of a market economy, but to demonstrate its stability at a level well below full employment.

The destructive part of the GT showed why the economy was not self-adjusting at full employment. According to the classical theory, two price-adjustment mechanisms, flexible wages and flexible interests, were supposed to validate Say's law. Keynes aimed to show how they could be inoperative. Flexible money wages would not necessarily cure unemployment, as wage cuts would reduce money demand (prices) 'in almost the same proportion, leaving the real wage and the level of unemployment practically the same as before' (Keynes 1936 [1978], p. 12; see pp. 262-269 for the 'Keynes effect'). Flexible interest rates would not necessarily eliminate the excess of saving over planned investment, as they were determined in the money market, not the market for saving and investment. Interest is the 'price' of giving up money, and a fall in the expected profit rate leads to a rise in 'liquidity preference' and therefore to a rise, not a fall, in interest rates. The classical theory thus lacked logical completeness. With the two classical priceadjustment mechanisms 'out of action', adjustment is secured by a fall in output and employment. 'Quantities adjust, not prices' was the flag under which the Keynesian revolution sailed.

How much output will need to fall to attain 'under-employment equilibrium' - a point at which output falls no further - is given by the size of the multiplier. This is determined by the marginal propensity to save and - in an open economy - by the marginal propensity to import. The multiplier was a technical device invented by Keynes's pupil Richard Kahn in 1931 to measure the total effect of changes in spending on national income: the effect of a given change in spending on national income is a calculable multiple of the change. 


\section{POLICY IMPLICATIONS}

The GT was a work of pure theory. But it had large implications for policy. Not only did competitive markets not assure continuous full employment, but following a large shock to investment, full employment would not recover automatically, and would have to be made to recover by some mix of monetary and fiscal policy. Policy should be designed to prevent such shocks from occurring. The government should stand ready to offset any fall in private demand or, better still, act continuously to prevent it. The GT thus marked the birth of macroeconomic policy as it was pursued until the 1970s. Monetary policy aiming to stabilize the price level was transformed into macroeconomic policy aiming to stabilize output at a level providing work for all those who wanted it.

The government's task was to add to total spending in a slump, and withdraw it from the economy in a boom. In reaction to the inordinate hopes of the monetary reformers in the 1920 s, monetary policy was now discarded as an economic regulator. 'It is not suitable to be used as a short-term weapon', as Keynes had stated dogmatically in 1937 (p. 389) - that fell to fiscal policy. The multiplier was the policy tool that would calculate how much extra spending needed to be injected into the economy to restore full employment (or alternatively to be withdrawn from it).

The equation for output could be written:

$$
Y=C+I+G
$$

with $G$, the fiscal stance, as the balancer.

The GT was a 'closed economy' model. But consider an open economy:

$$
Y=C+I+G+X(\text { net exports })+K A \text { (capital account). }
$$

The equilibrium condition for the balance of payments is that $X+K A=0$. So either the exchange rate or the domestic interest rate and/or the income level must adjust to secure balance-of-payments equilibrium. Keynes's critique of the gold standard, with the exchange rate fixed, was that balance-of-payments equilibrium required an interest rate too high for full employment.

It was an inherent quality of the gold standard (or any permanently fixed exchangerate system) that it failed to guarantee such an equilibrium. Keynes (1941 [1978], pp. 28-31) explained the failure of the postwar gold standard, and its contribution to the Great Depression, in terms of gold hoarding by the creditor countries: under the gold standard, adjustment was 'compulsory for the debtor and voluntary for the creditor ... The debtor must borrow; the creditor is under no ... compulsion [to lend]' (original emphases). This threw the burden of adjustment on the debtor country which would have to deflate its economy to regain balance-of-payments equilibrium. In the nineteenth century, massive capital exports from London, and to a lesser extent Paris, 'caused the burden to be carried by the stronger shoulders' (ibid.). In the first phase after the war, a large part of the flow - mainly from the USA - was not for developing new resources, but for financing war debts or commodity restriction schemes. During the Great Depression 'complete degeneration set in' (ibid.) and refugee capital flowed from debtors to creditors. Keynes concluded that a viable international system must provide for creditor adjustment, and that capital movements would need to be regulated.

This was Keynes's economics. Its logic was starting to sweep away the cobwebs of Victorian finance even before he had finished The General Theory. 
In his 'Means to Prosperity' (1933b [1978]), Keynes had followed Lloyd George's 1929 pledge to conquer unemployment with an argument for a deficit-financed programme of public works, this time backed up by the multiplier. The Treasury's initial reaction was predictable. 'It would be impossible', Sir Richard Hopkins minuted, to stop a 'rising tide of expenditure ... once we had abandoned the principle of paying our way' (quoted in Peden 2000, p. 265).

By 1937, the mood was more receptive. With fears of a new recession, the Treasury agreed to introduce a limited public works scheme under the condition that it would jeopardize neither interest rates nor confidence (Tomlinson 1987, p. 115; see Middleton 1985, ch. 8, for a review of the politics surrounding the Treasury View and public works); and the following year the Chancellor, Sir John Simon, put to the Cabinet a suggestion for a building programme to be prepared by local authorities (Howson and Winch 1977, p. 142; see also ch. 5 for an account of how Keynes's ideas started to make inroads into the Treasury by the later 1930s). However, these halting steps to acceptance were soon swamped by the much more clamant need for rearmament. In 1937, the Treasury accepted a five-year defence loan of $£ 400 \mathrm{~m}$. Borrowing for defence raised no new issues. But the Treasury still worried that the money raised for defence would 'crowd out' private spending by causing interest rates to rise and confidence in government finance to fall (Tomlinson 1987, p. 116).

\section{CONCLUSION}

The coming of Keynes to Britain forces us to think about the relationship between events, ideas, politics and policy.

One issue concerns the relationship between economic ideas and public policy. In monetary policy there was always a gap between the ideas of the theorists and the ideas of practical men, especially central bankers. This goes back to the seventeenth century. Debates concerning the nature of money cut across the two. But the main divergence before 1931 was that the monetary reformers believed that the central bank could control the quantity of money, and central bankers insisted that the only feasible control mechanism was the gold standard.

In fiscal policy, academic and policy views were better aligned. There is no one-toone relationship between economic ideas and policy; between the two stood institutional traditions and limits. However, ultimately ('indirectly') the Treasury View reflected an economic model of the economy in which all the factors of production were continually employed by the private sector; deviations from this optimal condition were shallow and transient. The fact that this was implicit rather than formal does not mean it was not part of a common mindset.

It could reasonably be held that it was dire events that forced changes in policy. Hitler, it was said, cured unemployment in Germany before Keynes had finished explaining why it happened; Roosevelt's New Deal was innocent of what Americans called the 'New Economics'. But ideas are not to be disposed of so easily. Hitler's cure for unemployment was certainly not bereft of ideas. It was just that they were not Keynes's ideas. He wanted Germany to be at full capacity in order to prepare for a war of conquest. Roosevelt's New Deal was a mish-mash of ideas, many of them inconsistent, swirling round in the mind of this arch-pragmatist. Keynes's dictum that practical men are slaves to defunct thinkers is not therefore wide of the mark. The important point here is that policies can have Keynesian effects, even if they are not done for Keynesian reasons. Building churches and fighting wars have always absorbed excess capacity. 
The more focused question concerns the relationship between economic ideas and politics. Do politicians simply use economic ideas to rationalize economic policies they want to pursue for other reasons - to help them conquer territories, win votes, pacify dissent, put them in good standing with the business community? Or are they genuinely influenced by economic arguments? And of the many competing economic ideas for dealing with economic crisis, what is it that causes some to succeed, others to fail? Evidently it would be wrong to ignore the vested interests of the wealthy and the powerful (though these might not be the same).

The key conclusion is that Keynesian economics offered an escape from a blocked system. This system was well described by Sir Josiah Stamp in his 11 June 1931 letter to The Times, drawing on insight from the French economist Jacques Rueff:

Instead of allowing economic forces to operate freely, the tendency [in the UK] since the War, has everywhere been in the opposite direction. The dole policy, the activities of the trade unions, and the employers' associations, and the various hindrances to migration have all interfered with the freedom of the labour markets. At the same time the activities of trusts, cartels, and marketing schemes have all retarded or suppressed the indispensable movement of prices. In a word, the organism has been drugged and paralysed. Hence the present deplorable situation. (Cited in Grant 2014, p. 208)

Any policy to combat unemployment which sought to unblock the paralysed adjustment mechanism committed politicians to fighting the class war. For the Right, it meant destroying or at least weakening trade unions, and restricting tax-funded alternatives to work. For the Left, it implied a revolutionary assault on the capitalist system itself. The encroachment of wages on profits could only be overcome by abolishing profits, that is, capitalism. The idea of the blocked system was central in Beatrice and Sidney Webb's The Decay of Capitalist Civilization (1923). In most western democracies, however, there was no political support for carrying either remedy to such extremes. The balance of forces was such that no outright victory was possible in the class war. Equally there was no intellectual foundation for a middle way.

This, in essence, is what the Keynesian Revolution provided. On 1 January 1935, he wrote to Bernard Shaw: 'To understand my state of mind you have to know that I believe myself to be writing a book on economic theory, which will largely revolutionise ... the way the world thinks about economic problems ... In particular, the Ricardian foundations of Marxism will be knocked away' (cited in Skidelsky 1992, pp. 520-521).

Or, as he wrote in the New Republic on 29 July 1940: 'If the community's aggregate rate of spending can be regulated, the way in which personal incomes are spent can be safely left free and individual' (cited in Skidelsky 2010, p. 153).

\section{REFERENCES}

Brown, W.A. (1940) The International Gold Standard Reinterpreted, 1914-1934. New York, NY: National Bureau of Economic Research.

Burrows, G. and Cobbin, P. (2009) Controlling Government Expenditure by External Review: The 1921 'Geddes Axe'. Accounting History, 14 (3), 199-220.

Cannan, E. (1919) The Paper Pound of 1797-1821. London: P.S. King \& Son.

Clarke, P. (1988) The Keynesian Revolution in the Making, 1924-1936. Oxford: Clarendon Press.

Eichengreen, B. (ed.) (1985) The Gold Standard in Theory and History. New York, NY: Methuen. 
Eichengreen, B. (1995) Golden Fetters: The Gold Standard and the Great Depression 19191939. New York, NY: Oxford University Press.

Friedman, M. and Schwartz, A.J. (1965) The Great Contraction 1929-1933. New York, NY: National Bureau of Economic Research.

Grant, J. (2014) The Forgotten Depression. New York, NY: Simon \& Schuster.

Hawtrey, R.G. (1913 [1962]) Good and Bad Trade: An Inquiry into the Causes of Trade Fluctuations. New York, NY: Kelley.

Hawtrey, R.G. (1925) Public Expenditure and the Demand for Labour. Economica, 13, 38-48.

HC Deb (15 April 1929) Hansard, vol. 227, col. 54.

Howson, S. and Winch, D. (1977) The Economic Advisory Council 1930-1939: A Study in Economic Advice During Depression and Recovery. Cambridge, UK: Cambridge University Press.

Keynes, J.M. (1923 [1978]) Tract on Monetary Reform. In Johnson, E. and Moggridge, D. (eds) The Collected Writings of John Maynard Keynes, Vol. 4. Cambridge, UK: Cambridge University Press.

Keynes, J.M. (1930a [1978]) A Treatise on Money. In Johnson, E. and Moggridge, D. (eds) The Collected Writings of John Maynard Keynes, Vol. 6. Cambridge, UK: Cambridge University Press.

Keynes, J.M. (1930b [1978]) Credit Control. In Johnson, E. and Moggridge, D. (eds) The Collected Writings of John Maynard Keynes, Vol. 11. Cambridge, UK: Cambridge University Press, pp. 420-427.

Keynes, J.M. (1933a [1978]) Spending and Saving. In Johnson, E. and Moggridge, D. (eds) The Collected Writings of John Maynard Keynes, Vol. 21. Cambridge, UK: Cambridge University Press, pp. 145-154.

Keynes, J.M. (1933b [1978]) The Means to Prosperity. In Johnson, E. and Moggridge, D. (eds) The Collected Writings of John Maynard Keynes, Vol. 9. Cambridge, UK: Cambridge University Press, pp. 335-366.

Keynes, J.M. (1936 [1978]) The General Theory of Employment, Interest, and Money. In Johnson, E. and Moggridge, D. (eds) The Collected Writings of John Maynard Keynes, Vol. 7. Cambridge, UK: Cambridge University Press.

Keynes, J.M. (1937 [1978]) Slump and Rearmament. In Johnson, E. and Moggridge, D. (eds) The Collected Writings of John Maynard Keynes, Vol. 21. Cambridge, UK: Cambridge University Press.

Keynes, J.M. (1941 [1978]) The Origins of the Clearing Union, 1940-1942. In Johnson, E. and Moggridge, D. (eds) The Collected Writings of John Maynard Keynes, Vol. 25. Cambridge, UK: Cambridge University Press.

Keynes, J.M. and Henderson, H. (1929 [1978]) Can Lloyd George Do It? In Johnson, E. and Moggridge, D. (eds.) The Collected Writings of John Maynard Keynes, Vol. 9. Cambridge, UK: Cambridge University Press, pp. 86-125.

Kindleberger, C.P. (1973) The World in Depression, 1929-1939. Berkeley and Los Angeles, CA: University of California Press.

Maier, C. (1975) Recasting Bourgeois Europe. Princeton, NJ: Princeton University Press.

Middlemas, K. and Barnes, A.J.L. (1969) Baldwin: A Biography. London: Weidenfeld \& Nicolson.

Middleton, R. (1985) Towards the Managed Economy: Keynes, the Treasury and the Fiscal Policy Debate of the 1930s. London: Methuen.

Niemeyer, O. (1921) Niemeyer to Chancellor, 5 October 1921, T 172/1208.

Peden, G.C. (1993) The Road to and from Gairloch: Lloyd George, Unemployment, Inflation, and the 'Treasury View' in 1921. Twentieth Century British History, 4 (3), 224-249.

Peden, G.C. (2000) The Treasury and British Public Policy, 1906-1959. Oxford: Oxford University Press.

Peden, G.C. (ed.) (2004) Keynes and his Critics: Treasury Responses to the Keynesian Revolution, 1925-1946. Oxford: Oxford University Press.

Schumacher, E. (1944) Public Finance - Its Relation to Full Employment. In Oxford Institute of Statistics (ed.), The Economics of Full Employment. Oxford: Blackwell. 
Skidelsky, R. (1981) Keynes and the Treasury View: The Case For and Against an Active Unemployment Policy, 1920-1939. In Mommsen, W.J. (ed.) The Emergence of the Welfare State in Britain and Germany. London: Croom Helm, pp. 167-187.

Skidelsky, R. (1992) The Economist as Saviour. London: Penguin Books.

Skidelsky, R. (2010) Keynes: The Return of the Master. London: Penguin Books.

Skidelsky, R. (2015) Five Years Crisis. London: Centre for Global Studies.

Tomlinson, J. (1987) Employment Policy: The Crucial Years 1949-1955. Oxford: Clarendon Press.

Webb, S. and Webb, B. (1923) The Decay of Capitalist Civilisation. Westminster: Fabian Society/Allen and Unwin. 